\title{
Gender Equity Employment in Polytechnics in South East Zone of Nigeria: Implication for Affirmative Action
}

Obiagwu, Clara O. (PhD) \& Unachukwu, G. O. (PhD)

\section{Abstract:}

This study was carried out on the Gender Equity Employment status in Polytechnics in South East Zone of Nigeria: Implications of Affirmative Action. The Study was guided by three research questions and one null hypothesis. The population of the study was eight (8) registrars of both Federal owned and State-owned polytechnics in South East Zone of Nigeria. As an ex-post factor type of study, the researchers provided a guided record-providing sheet for the collection of data required for the study. The result from the data analyzed among others revealed that 656 or 64.76 percent of academic staff in polytechnics were males while 357 or 35.24 percent were females. Also, 1,198 or 46.94 percent out of 2,552 non-academic staff were males where 1,354 Or 53.06 percent were females. Based on these findings and implications for affirmative action, recommendations were made.

\section{Introduction}

Section 18 of the 1999 Nigeria Constitution provides for equal educational opportunities at all levels for every citizen. Equally it provides for the provision of free, compulsory and universal primary education, free secondary education, free university education and free adult literacy programme (Federal Republic of Nigeria, FRN 1999). The abridged version of the Nigerian Child's Rights Act,2003 states that every child has the right to free, compulsory basic education to be provided by the government. Every parent or guardian shall ensure that his ward attends and completes his primary, junior 
and senior secondary school or learns a trade. Chapter 2 of the Nigerian constitution provides for equality and equal work for equal pay. This chapter enjoins the state to direct its policies towards ensuring that all citizens, without discrimination, secure adequate means of livelihood as well as adequate opportunity to secure suitable employment (FRN, 1999). According to Ezeilo (2004), the State is expected to make conditions of work just, humane and provide for the health, safety and welfare of persons in employment, endangered or abused. In employment also, Section 17 (3) (e) of the 1999 Nigerian Constitution provides for equal pay for equal work without discrimination on the basis of sex or any other ground whatsoever. Section 42 of this same 1999 Nigerian Constitution provides for non-discrimination on the basis of sex.

Several policies and programmes have been adopted and declared by the Federal Government towards the improvement of women in Nigeria. Notable amongst which are the Social Development Policy 1989, the National Policy on Women 2000, Universal Basic Education, and the Blue Print on Women's Education Development by the Federal Ministry of Education, set to achieve full gender equity in access and participation in education at all levels (Ezeilo, 2004) In addition, there are the National Human Rights Commission (NHRC) with a gender desk, the Poverty Eradication Initiative, the National Action Committee on Women in Politics (NACWIP) to aid greater participation of women in politics and the Revised National Policy on Education 2004 which encourages girls to undertake technical education. The National Policy on Women Provides that women require basic education to enjoy 
Gender Equity Employment in Polytechnics...

the full benefits of contemporary living and to contribute meaningfully to the development of the country.

In spite of equal Constitutional provisions for both sexes there is persistent gender inequalities in both educational and employment attainment between females and males. According to Fafunwa (1974) the Christian missions introduced male-oriented education when they came. Awe (1990), cited in Ezumah (2001) says that this had a great effect in the establishment of schools and the curricula for girls and boys. According to World Bank (1992), parents preferred to educate boys and girls were encouraged to engage in early marriages or were made to do the house chores like fetching water, preparing food, gathering firewood, looking after the younger children. Okwo (2001) shows that male-female enrolment patterns in primary schools and universities were not stable but stable in secondary schools with gender differentials consistently in favour of girls. Uduchukwu (2001) observes that there is gender inequality in the enrolment figures in favour of males. Enrolment of females of at the University of Nigeria Nsukka, according to her was 36.6 percent while that of males was 63.4 percent. According to the research work, females are below average in most faculties and courses except in Arts, Education, Biological Sciences, Social Sciences and Health Sciences and Health Science and Sub-degree, first degree, post-graduate diploma, certificate courses and higher degree courses. She says that there is disparity in the number of graduated females compared with their counterparts in male dominated courses like Medicine, Engineering, Science and technology, et cetera. Maynard (1992) sees gender as the social attributes and opportunities associated with being male and female and the relationships between women and men and girls and boys, as well as the relations between women and those between men. These attributes, opportunities and relationships are socially 
constructed and are learned through socialization processes. They are context/time-specific and changeable. Gender equity is a process of being fair to women/girls and men/boys. Gender Equity Employment Status is the state or rate of intake of workers in employment by gender. The United Nations (UN) went through several conventions and recommendations to bring about equal opportunities in employment. The outcome of one of the Conventions (Convention on the Elimination of All Forms of Discrimination Against Women, (CEDAW) gave rise to the affirmative action. This affirmative action of 30:70 percent females and males representations is a temporary measure designed to end or remove discrimination in employment on the basis of gender. This study sets to determine the rate of intake of workers in employment by gender in specific areas of academic and non-academic staff in Polytechnics in South East Zone of Nigeria.

\section{Statement of the Problem}

There are no recorded statistical evidences to show that there is discrimination in employment in Polytechnics in South East Zone of Nigeria. There is also no statistical evidence to show that males are also found in the managerial positions in these Polytechnics. The problem of this study is to find out the Gender Equity Employment Status in specific areas of academic and non-academic staff in Polytechnics in South East Zone of Nigeria

\section{Purpose of the Study}

The main purpose of this study is to find out the Gender Equity Employment status in Polytechnics in South East Zone of Nigeria. Specifically the study looked at: 
Gender Equity Employment in Polytechnics...

1. the Gender Equity Employment Status in Federal-owned Polytechnics in South East Zone of Nigeria.

2. The Gender Equity Employment Status in State-owned Polytechnics in South East Zone of Nigeria

3. the Gender Equity Employment Status in both Federal owned and State-owned Polytechnics in South East Zone of Nigeria.

4. the difference in Gender Equity Employment Status between Federal-owned and State-owned Polytechnics in South East Zone of Nigeria.

\section{Scope of the Study}

The study was based on the Gender Equity Employment in Specific areas of academic and non-academic staff in Polytechnics in South East Zone of Nigeria.

\section{Research Questions}

1. What is the Gender Equity Employment status in Federal-owned Polytechnics in South East Zone of Nigeria?

2. What is the Gender Equity Employment status in Stateowned Polytechnics in South East Zone of Nigeria?

3. What is the Gender Equity Employment status in both Federal-owned and State-owned Polytechnics in South East Zone of Nigeria?

\section{Null Hypothesis}

1. There is no significant difference in the Gender Equity Employment Status between Federal-owned and Stateowned Polytechnics in South East Zone of Nigeria.

\section{Methodology}

This study is ex-post facto type because the information sought is already in existence and the researcher 
cannot manipulate it. The population of the study was made up of five registrars from the federal-owned Polytechnics and three registrars from the State-owned Polytechnics. There was no need for sample and sampling technique due to the research design. The instrument used was a guided figure base record-providing sheet which was validated by three experts from Faculty of Education, Nnamdi Azikiwe University Awka, Anambra State (two from the Department of Educational management and Policy and one from Measurement and Evaluation). There was no need for the reliability of the instrument due to the design. The data collected were analysed using frequency tables and percentages for the research questions and chi-square $\left(X^{2}\right)$ for the null hypothesis.

\section{Result}

\section{Research Question 1}

What is the Gender Equity Employment status in Federalowned Polytechnics in South East Zone of Nigeria?

\section{Table 1}

Frequency and Percentage distribution of gender Equity Employment Status in Federal-owned Polytechnics in South East Zone of Nigeria;

\begin{tabular}{|l|l|l|l|c|l|}
\hline \multirow{2}{*}{ Specifications } & \multicolumn{2}{|c|}{ Male } & \multicolumn{2}{c|}{ female } & Total \\
\cline { 2 - 5 } & Freq & \multicolumn{1}{|c|}{$\%$} & Freq & $\%$ & \\
\hline Academic Staff & 510 & 67.64 & 244 & 32.36 & 754 \\
\hline $\begin{array}{l}\text { Non-Academic } \\
\text { staff }\end{array}$ & 698 & 46.90 & 790 & 53.10 & 1,488 \\
\hline $\begin{array}{l}\text { Directors of } \\
\text { Programmes }\end{array}$ & 15 & 93.75 & 1 & 6.25 & 16 \\
\hline $\begin{array}{l}\text { Head of } \\
\text { Departments }\end{array}$ & 58 & 80.56 & 14 & 19.44 & 72 \\
\hline Unit Coordinators & 10 & 76.92 & 3 & 23.08 & 13 \\
\hline $\begin{array}{l}\text { Chairmen of } \\
\text { Committees }\end{array}$ & 11 & 78.57 & 3 & 21.43 & 14 \\
\hline
\end{tabular}


Gender Equity Employment in Polytechnics...

The table above shows that out of 754 Academic Staff, 510 representing 67.74 percent were males while 244 or 32.36 percent were females. 698 or 46.90 percent out of 1,488 nonacademic staff were males where 799 or 53.10 were females. Out of 16 Directors of Programmes 15 or 93.75 percent were females while only 1 or 6.25 was a female. Also 58 or 80.56 percent out of 72 Heads of departments were males while 13 Unit Coordinators were males while 14 or 19.44 percent were females. Finally, out of 14 Chairmen of committees 11 or 78.57 percent were males while 3 or 21.43 percent were females.

\section{Research Question 2}

What is the Gender Equity Employment status in Stateowned Polytechnics in South East Zone of Nigeria?

\section{Table 2}

Frequency and Percentage distribution of gender Equity Employment Status in State-owned Polytechnics in South East Zone of Nigeria:

\begin{tabular}{|c|c|c|c|c|c|}
\hline \multirow[t]{2}{*}{ Specifications } & \multicolumn{2}{|c|}{ Male } & \multicolumn{2}{|c|}{ female } & \multirow[t]{2}{*}{ Total } \\
\hline & Freq & $\%$ & Freq & $\%$ & \\
\hline Academic Staff & 146 & 56.37 & 113 & 43.63 & 259 \\
\hline $\begin{array}{l}\text { Non-Academic } \\
\text { staff }\end{array}$ & 504 & 47.37 & 560 & 52.63 & 1,064 \\
\hline $\begin{array}{ll}\text { Directors } & \text { of } \\
\text { Programmes } & \end{array}$ & 12 & 92.30 & 1 & 7.70 & 13 \\
\hline $\begin{array}{l}\text { Head of } \\
\text { Departments }\end{array}$ & 48 & 85.71 & 8 & 14.29 & 56 \\
\hline Unit Coordinators & 1 & 50.00 & 1 & 50.00 & 2 \\
\hline $\begin{array}{ll}\text { Chairmen } & \text { of } \\
\text { Committees }\end{array}$ & 19 & 86.36 & 3 & 13.64 & 22 \\
\hline
\end{tabular}

Table 2 shows that 146 of 56.37 out of 259 Academic Staff were males while 113 or 43.63 were females. Also 504 or 43.37 percent out of 1,064 non academic staff were males 
560 or 52.63 percent were females. Out of 12 directors of Programmes, 12 or 92.30 were ales while 1 or 7.70 was a female. Also 48 or 85.71 percent out of 56 Heads of Departments were males where 8 or 14.29 were females. Again 1 or 50 percent of the 2 unit Coordinators was a male, likewise 1 or 50 percent was a female. Finally, out of 22 Chairmen of Committees, 19 or 86.35 percent were males while 3 or 13.64 percent were females.

\section{Research Question 3}

What is the Gender Equity Employment status in both Federal-owned and State-owned Polytechnics in South East Zone of Nigeria?

\section{Table 3}

\begin{tabular}{|l|l|l|l|l|l|}
\hline \multirow{2}{*}{ Specifications } & \multicolumn{2}{|c|}{ Male } & \multicolumn{2}{c|}{ female } & \multirow{2}{*}{ Total } \\
\cline { 2 - 5 } & Freq & \% & Freq & \% & \\
\hline Academic Staff & 656 & 64.76 & 357 & 35.24 & 1,013 \\
\hline $\begin{array}{l}\text { Non-Academic } \\
\text { staff }\end{array}$ & 1,198 & 46.94 & 1,354 & 53.06 & 2,552 \\
\hline $\begin{array}{l}\text { Directors of } \\
\text { Programmes }\end{array}$ & 27 & 93.10 & 2 & 6.90 & 29 \\
\hline $\begin{array}{l}\text { Head of } \\
\text { Departments }\end{array}$ & 106 & 82.81 & 22 & 17.19 & 128 \\
\hline Unit Coordinators & 11 & 73.33 & 4 & 26.67 & 15 \\
\hline $\begin{array}{l}\text { Chairmen of } \\
\text { Committees }\end{array}$ & 30 & 83.33 & 6 & 16.67 & 36 \\
\hline
\end{tabular}

Table 3 shows that 656 of 64.76 of Academic Staff in both Federal and State-owned Polytechnics were males while 357 or 35.24 percent were females. Also 1,198 Or 46.94 percent out of 2,552 non academic staff were males where 1,354 or 53.06 percent were females. Out of 29 directors of Programmes, 27 or 93.10 were males while 2 or 6.90 were 
Gender Equity Employment in Polytechnics...

females. Also 106 or 82.81 percent out of 128 Heads of Departments were males where 22 or 17.19 were females. Again 11 or 73.33 percent of the 15 unit Coordinators were males, where 4 or 26.67 percent were females. Finally, out of 30 or 83.33 percent of the 36 Chairmen of Committees, were males while 6 or 16.67 percent were females.

\section{Null Hypothesis 1}

There will be no significant difference in the Gender Equity Employment Status in Federal-owned and State-owned Polytechnics in South East Zone of Nigeria.

Table 4: Chi Square $\left(\left(X^{2}\right)\right.$ Summary on Gender Equity Employment Status in Federal-owned and State-owned Polytechnics in South East Zone of Nigeria,

\begin{tabular}{|l|l|l|l|l|l|l|}
\hline Sources of Variation & $\begin{array}{l}\text { Federal } \\
\text { Polytechnics }\end{array}$ & $\begin{array}{l}\text { State } \\
\text { Polytechnics }\end{array}$ & Df & Cal X & $\begin{array}{l}\text { Crit } \\
\mathrm{X}^{2}\end{array}$ & $\mathrm{P}>0.05$ \\
\hline Academic Staff 1 & 510 & 146 & & & & \\
Academic Staff 2 & 244 & 113 & & & & \\
Non-Academic Staff 1 & 698 & 504 & & & \\
Non-Academic Staff 2 & 790 & 560 & & & \\
Directors 1 & 15 & 12 & & & \\
Directors 2 & 1 & 1 & & & \\
Heads of Dept 1 & 58 & 48 & & & \\
Heads of Dept 2 & 14 & 8 & & & & \\
Unit Coordinators 1 & 10 & 1 & & & & \\
Unit Coordinators 2 & 3 & 19 & & & & \\
Chairmen of Com. 1 & 11 & 3 & 11 & 105.96 & 19.68 & $* 0.05$ \\
Chairmen of Com.2 & 3 & & & & \\
\hline Total & & & & & \\
\hline
\end{tabular}

$1=$ Male $2=$ Females $* 0.05$

Table 4 above shows the Chi Square $\left(X^{2}\right)$ summary on Gender Equity Employment Status in Federal-owned and State owned Polytechnics in South East Zone of Nigeria. The table indicates that at 0.05 level of significance and 11 degree of Freedom, The calculated $X^{2} 105.96$ is greater than the critical $X^{2} 19.68$. Therefore, the null hypothesis is rejected and the alternative accepted. The writers then conclude that there is significant 
difference in the Gender Equity Employment Status in Federal owned and State owned Polytechnics in South East Zone of Nigeria.

\section{Discussion}

From the analyses, it was found that the male academic staff in Federal-owned Polytechnics were 67.64 percent while the females were 32.36 percent; 56.37 percent for males and 43.63 percent for females in State-owned Polytechnics, for both 64.76 for males and 35.24 for females. The male non-Academic staff were 46.90 and females 53.10 in Federal-owned Polytechnics; 43.37 percent for males and 52.63 percent for females in the state-owned Polytechnics and 46.94 percent for males and 53. 06 percent for females for both Federal-owned and State-owned Polytechnics. The analyses also show that there is significant difference in the Gender Equity Employment Status. Oyewo (2001), who carried out a research on the Background Traits of Women in Nontraditional Occupation as well as the Perspectives of Married Professional Women, found out that the most highly rated background was that women in male-dominated jobs are more likely to be better educated. Research Studies carried out in Lagos State by Bolarin (1996) show that students in girls' Secondary Schools cited three reasons of their not choosing to enroll in Science Courses. These reasons are as follows: Science Subjects are difficult to understand; Science subjects are hard and Science subjects are mainly for male students. Njoku (2001) shows that the number of girls and women who obtained education and training at all levels is below female proportion in the Nigerian population. The result also shows that as the level of education rises, the proportion of all 
Gender Equity Employment in Polytechnics...

students that are females dwindles. The lowest proportions were in Polytechnics and Universities. It shows that there is high attrition rate at the transition point from the Secondary level to the tertiary level. According to Umoru and Inalegwu (2007), the Registrar and Chif Executive of Joint Admissions and Matriculations Board (JAMB), Professor Dibu Ojerinde says that:

One of the reasons for the decline in candidates seeking admission into technical and teaching professions is because of the Government's reform policies that affect Polytechnics as it now wants to admit candidates into degree courses rather than into Ordinary/Higher National Diploma (OND/HND)

The Professor reveals that that the number o candidates that put in for this Year's examinations has reduced by 6,152 (3.7\%) when compared to 2006 where the effect would be on academic staff in future. The analyses of this study show that males are below 70 percent affirmative action which is not that significant and females above 30 percent which is also not significant except in State-owned Polytechnics -43.63 representation for females.

The percentage of females among non-academic staff is more than that of females-53.10 percent females and 46.90 percent males in Federal-owned Polytechnics; 52. 63 percent females and 47.37 percent males in State-owned Polytechnics; 53.06 percent females and 46.94 percent males in both Federal -owned Polytechnics and State-owned Polytechnics. Anticipated family responsibilities are believed to influence parents' and females' decisions about the amount and kind of investment in education and training. For example, the number of years of schooling, subject matter of course work and general versus firm-specific training, as well as pattern of time devoted to employment. Females are most likely to 
prefer employment in jobs in which wage growth is not closely linked to skill acquisition. Married females continued to be largely responsible for childcare and other energy intensive household responsibilities. Due to the fact that they consequently expend more effort than men on these family duties, it arguably reduces the effort that females' occupational preferences by encouraging them to economize on the energy they expend on employment. The growth in females' employment has not been matched by the quality of jobs they have access to. Looking at the analyses, females are mostly found in neutral occupations.

In appointments into Directorship, Headship, Unit Coordinators and Chairmen of Committees, men range from 93.10 percent to 50 percent while females are 6.25 percent to 26. 67 percent and 50 percent for Unit Coordinator in only one Polytechnic. The analyses show that males are above 70 percent and females below 30 percent affirmative action set out for gender equity. The traditional practices and the refusal to path with our traditional customs worsen the conditions of females in Nigeria. Aweda (1988) cited in Ezumah (2001), says that females' employment in the executive, administrative, scientific and technical professions remained minimal. These positions are based on appointments. Larwood and Gattiker (1995), cited in Trentham and Larwood (1998), in their Rational Bias theory, state that there are instances in which engaging in discrimination seems justified to an employee, even though he or she may personally prefer to treat others equally. Employees in decision-making position understand that they have to take into account the attitudes and preferences of other people, such as superiors, clients, in order to enhance and develop their own careers. It follows 
Gender Equity Employment in Polytechnics...

that decision-makers may choose to discriminate if they believe their superiors or other having having power over their career except or prefer it. Trentham and Larwood (1998) state that despite regulations that attempt to promote equality within the workplace, discrimination against certain social groups such as women still occurs, with women faring worse than men on most measures of economic equity. They said that although women are increasing their numbers in managerial and executive positions, those positions are still generally dominated by men.

\section{Conclusion}

This paper highlighted some of the policies and programmes adopted and declared by the Federal Government towards the improvement of gender equality. Though laws exist, ignorance of the existing laws and measures, attitudinal practices by some employers, inadequate legislative provisions coupled with gender stereotypes had greatly affected the access of women in equal employment opportunities. Changes in cultural values are slow and an idealized family morality is resistant to change. This is evident in the analysis made in this work. Females represent 35.24 percent of academic staff, 53.06 percent of nonacademic staff, 6.90 percent to 26.67 percent in the executive and administrative positions that require decision-making. The affirmative action of 30:70 percent female and male representations was designed to end discrimination in employment on the basis of gender. This action is insufficient if some groups enter the labour market from unequal starting point due to a history of discrimination.

\section{Implications for Affirmative Action}

1. Nigeria has not translated the affirmative action. There is no Federal legislation on affirmative action which will back up adequate opportunity for suitable employment without discrimination. 
2. The school curricula still remain strongly wedded to the partrilineal traditional in the society and many girls are not found in science and technical studies, thereby perpetrating the continued teaching of stereotypes about gender relations

3. Affirmative action as a tool for gender equality and females' empowerment will serve as a prerequisite for the achievement of sustainable development and end adverse poverty in the society.

\section{Recommendations}

The following recommendations were made

1. Decisions that would affect females in employment should be made gender sensitive to enable females participate in decision-making programmes.

2. The Government should provide, in collaboration with parents, non-governmental organizations, including youth organizations, communities and the private sectors, young females with academic and technical training, leadership and work experience to prepare and encourage them to take up appointments in Polytechnics.

3. Full implementation of laws, policies and programmes for full development and advancement of women is required.

4. The Federal Government should monitor and evaluate all policies at all levels of the implementation processes.

5. National Legislation to out law all discriminatory policies against women in the area of employment should be enacted. 
Gender Equity Employment in Polytechnics...

6. Creches with trained personnel should be available at all the Polytechnics.

\section{References}

Bolarin, T. A. (1996). "The Relationship between the Sex of Students and their Choice of Science Subjects" Unpublished Paper. Lagos State University.

Ezeilo, J (2004). Status of CEDAW Implementation in

Nigeria: A Shadow Report. Enugu. Women's Aid Collective (WACOL).

Ezumah, J. (2001) "Perspective on Gender Equality and Socio-Economic and Political Implications of Gender Inequality in Nigeria," in Nnaka, C. U. and Anaekwe, M.C. (eds). Towards Gender Equity in Nigeria in the 21 st Century. Enugu: Podiks.

Faunwa, B. A. (1974). History of Education in Nigeria.

London: George Allen and Unwin.

Federal Republic of Nigeria (1999). Constitution of the

Federal Republic of Nigeria. Lagos: Federal Government Press.

Federal Republic of Nigeria (2004). National Policy on

Education. Lagos: NERDC Press.

Maynard, C (1992). "Gender Difference in the Treatment and Outcomes of Acute Myocardial Infarctions" Archives of Internal Medicine.

Njoku, Z. C. (2001). "Improving Science and Technology

Education of Girls and Women in Nigeria: The Ways

Forward," in Nnaka, C. U. and Anaekwe, M. C. (eds.)

Towards Gender Equality in Nigeria in the 21st

Century. Enugu: Podiks.

Okwo, F. A. (2001). "School Enrolment and Gender:Trends and Implications", in Nnaka, C. U. and Anaekwe, M. C. (eds.) Towards Gender Equality in Nigeria in the 21st Century. Enugu: Podiks. 
Oyewo, N. A. (2001). "Background Traits of Women in Non-Traditional Occupations:The Perspectives of

Married Professional Women" Knowledge Review. Tntt vol.8, Nos. 1 and 2:33-34

Trentham, S. and Larwood, L (1998). Gender Discrimination and the Workplace: An Examination of Rational Bias Theory." Sex Role, A Journal of Research. New York: Columbia University Press.

Uduchukwu, A. N. (2001). "Gender Difference in Studens' Enrolment into Higher Institutions: A Case Study of University of Nigeria, Nsukka" Knowledge review. Tntt Vol. 8 Nos 1 and 2.

Umoru H. and Inalegwu, S. (2007). "JAMB Scribe Identifies

Reason for Poor Polytechnic, College of Education

Enrolment." Vanguard, Wednesday, August 1.

World Bank (1992). "Primary Education_A World Bank

Policy Paper." Washinton, D. C. The World Bank

Development in Practice Publiocations 